\title{
Khilafah Islamiah in International Islamic Political Perspective
}

\author{
$1^{\text {st }}$ Amsori $^{1}, 2^{\text {nd }}$ Ernawati $^{2}$ \\ \{amsori.sh@gmail.com ${ }^{1}$, ernawati@esaunggul.ac.id ${ }^{2}$ \} \\ STIH IBLAM, Department of Law, Jakarta, Indonesia ${ }^{1}$, \\ Esa unggul of University, Department of Law, Jakarta, Indonesia ${ }^{2}$
}

\begin{abstract}
Integralism of Islam and life can also be shown from the position of Islamic law in the Islamic teaching system. That Islamic law (the law sent down by God) is not limited to regulating human relations with God (habl min Allah), but also relationships with fellow humans (habl min al-Nas) and the life of the universe. Conceptual debates about the relationship of religion and state in the history of thought the classical and medieval centuries never really echoed strongly among Muslim thinkers because the political practices of Muslims in the Islamic Caliphate never separated religion and state. Applying Islamic sharia practically becomes the task of the caliph. This task was charged by the Messenger of Allah, so the Caliph ensured the application of Islamic law, and because of that he had to be appointed in the midst of the Muslims. The revival of Muslims will come when the people apply the Islamic Shari'ah as a whole in the auspices of the Khilafah Islamiyah, and the destruction of Muslims begins when the people ignore the application of Islamic sharia, and only apply Islam in ritual worship alone.
\end{abstract}

Keywords: Islamic Khilafah, Caliph, Islamic Politics

\section{Introduction}

In conceptualizing Islam, Muslims face two intellectual problems. First, when Islam is believed to be a religion based on God's revelation, Muslims face problems involving the relationship between revelation and reason. Secondly, when Islam is believed to be a religion consisting of teachings on all aspects of life, Muslims face the problem of the relationship between religious issues and worldly (secular) problems. This factor has created two big problems in Islamic thought in general and Islamic political thought in particular. It can be said, that the problem of Islamic political thought becomes two major themes, namely the relationship between revelation and reason, and the relationship between religion and politics [1].

If we look at the course of Islamic history, especially the period of the Holy Prophet, and the Khulafa al-Rashidun, it can be seen that the activities carried out by the Prophet, both while still in Mecca and while in Medina, were not only focused on the question of monotheism, but also the problem of social life, even politics. This society was later united in a state and constitutional container which became known as the Medina Constitution [2]. With a cursory look at the history of Islamic politics, it can be understood that actually Islam has provided signs for people's lives. Because in his teachings there are values of justice ('a 
dalah), trust (Amanah), tolerance (tasamuh), and so on. These values should be developed by adherents of religion both in the life of society, nation and state [2].

Integralism of Islam and life can also be shown from the position of Islamic law in the Islamic teaching system. That Islamic law (the law sent down by God) is not limited to regulating human relations with God (habl min Allah), but also relationships with fellow humans (habl min al-Nas) and the life of the universe [3].

The conceptual debate about the relation between religion and state in the history of classical and medieval thought has never really been echoed strongly among Muslim thinkers because the political practices of Muslims in the Islamic Caliphate never separated religion and the state. Classical and medieval Muslim thinkers have witnessed the practice of integration of religion and state in the Islamic Caliphate (from the Rashidah Caliphate to the Ottoman Turks). Not surprisingly, Muslim thinkers, such as al-Mawardi (972-1058 AD), alGhazali (1058-1111 AD), Ibn Taymiyah (1263-1328 AD), Ibn Khaldu n (1332-1406 AD) and others have never debated the concept of religious and state relations. They have seen first hand the practice of religious and state relations that are integral (united) [4].

In this context, there is a disaggregation between groups who have views that unite religion and the state and groups that reject the unification of religion and state. The first group is often referred to as the fundamentalist and radical groups, while the second group is often referred to as the secular and liberal groups. Among the contradictions between the two groups above, a third group emerged, namely those who argued that Islam governs the problem of both the ultimate and the worldly (social) even though only in the form of general principles [5].

In this context, there is a disaggregation between groups who have views that unite religion and the state and groups that reject the unification of religion and state. The first group is often referred to as the fundamentalist and radical groups, while the second group is often referred to as the secular and liberal groups. Among the contradictions between the two groups above, a third group emerged, namely those who argued that Islam governs the problem of both the ultimate and the worldly (social) even though only in the form of general principles [5].

\section{Methodology}

This research is a qualitative normative juridical study that refers to data obtained from library materials. The results of the analysis are described descriptively, namely describing and explaining the data found in the study, so as to obtain a descriptive-qualitative description of the results of the research aimed at describing what currently applies. In it there are efforts to describe, record, analyze and interpret the conditions that currently occur or exist. In other words this qualitative descriptive study aims to obtain information about the existing situation.

\section{Methodology}

\subsection{Islam and Its Role}

The role of Islam in the Middle East has been very dominant since the development of Islam there. This role has been started since the time of the Prophet Muhammad and the 
Khulafa al-Rassyidin. This religion, along with its adherents, had for some seven centuries been the center of world cultural, scientific and technological progress. Its territory stretches from the Pyrene Mountains, on the border of France and Spain, to the Indus River in the Indian subcontinent and approaching the borders of China [6].

Then that role suffered a setback, in line with the rise of the Western star. Experts see two factors that led to the decline of Muslims. First, it is a factor in Muslims themselves. Islamic societies have turned into a porous society, so the understanding and practice of their religious teachings has turned into a frozen routine. The activeness, vitality, and creativity taught by their religion now only remains a memory. Reform movements in Islamic history, ranging from Ahmad bin Hanbal, Ibn Taimiyah, and Muhammad bin Abdul Wahab to Afghani, 'Abduh and Rasyid Ridha [4], are efforts intended to return Muslims to the purity of Islamic teachings, as well as to the vitality and creativity that he had [6]. The three Islamic thinkers represented a Muslim religious school of thought that was influential at the time, and their relationship between one and the other was the relationship between teacher and student. Abduh studied with Afghani, and Ridha studied with Abduh [4].

Second, is the increasing factor of the role of the West in world history, first in the field of shipping and weaponry, which then led to the Western occupation of almost the entire surface of the earth. The fall of the Islamic region into the Western occupation gave rise to admiration in the Muslim community for everything that came from the West and the desire to imitate all the progress and might that had been demonstrated. The tendency of modernism in Islamic circles can be said to stem from feelings of admiration for the West and its desire to imitate [6].

However, after the Islamic nations succeeded in gaining independence in the political field after World War II, they began to realize the deficiencies found in western civilization. Within them arises a desire to return to their authenticity. In the Middle East, figures such as Sayid Qutb, 'Audah, Thaha Hussein,' Aqqad and others, who later paid great attention to Islamic teachings, can be explained from this process. The emergence of movements that are often blamed with the name "fundamentalist" in the Islamic world today, is also in the context of efforts to apply to the extent possible each of what they consider to be the core of Islamic teachings. Although they have not succeeded in expressing the greatness of Islam as it should, this effort cannot be separated from the desire to see Islam move forward and give what is called rahmatan lil'alamin, namely a global order that benefits all parties, both Islam and nonIslamic ones. They have started it, despite all its shortcomings [6].

\subsection{Khilafah in Islamic Political History}

Khilafah according to the meaning of language is the mashdar of fi'il madhi Khalafa, which means replacing or occupying his place. According to Imam Athari Tabari the meaning of language is the reason why the highest authority of Muslims is called the Caliph. Namely, because he replaced the previous ruler. [7].

The institution which is responsible for implementing the Sharia laws and preaching Islam to all human beings is called the Khilafah. This title is given to the Islamic government system which is totally different from the existing government systems, which are based on the Book of Allah (Al-Quran) and the Sunnah of the Prophet (Al-Hadith). The appointment of a Khalifah for Muslims includes fardhu kifayah for all Muslims throughout the world.

A fairly articulate political theory from the Ahlisunnah eventually emerged in the first half of the 11 th century. His doctrine of the Caliphate quenched the thirst of the religious 
community who were in a state of confusion because of their drastic decline in expectations of the Caliphate, while still maintaining Abbasid legitimacy as Muslim leaders. The first four caliphs (khulafa al-rasyidin) now get a special category. The main thrust of this theory is to protect the Abbasid Caliphate from other alternatives - Shiite Imamiyah and Shiite Ismailiyah, especially from Fatimid families - who might appear as legitimate leaders in the eyes of the poor [8].

Jurists specifically discussed ways of establishing the caliph, as well as the basics for firing or canceling his authority. According to al-Baqillani, the knowledge of a caliph about the privileges of the personal qualities of a successor could not be used as a basis for appointing him as a caliph (as the Shi'ah opinion). However, the appointment can be done through appointment which is accompanied by an agreement ('ahd). As an alternative step, the caliph can be chosen by "the group that releases and binds (ahl al-hall wa al-'aqd)." [9] This kind of election (endeavor) is considered valid, even if carried out by only one person during witnessing by many Muslims [8].

Salafiah ideology bases itself on the assumption that the faith of the Ummah has strayed, and this in turn paralyzes Muslims in responding to the challenges of modern political life. This movement is rooted in the legacy of Islamic reformism Jamal al-Din al-Afghani and Muhammad Abduh which was intended to rehabilitate Muslims and reorganize the political power of the ummah. Rasyid Rida saw the need to reform the Islamic legal system and improve Islamic governance, namely the caliphate. For Rida, the correct political system is based on deliberation between the caliph and the ulama who is a guide for interpretations of Islamic law. Like pro-modern thinkers, Rida stated that the Caliphate was his legal obligation and this obligation was based on sharia and consensus (ijma').

From that perspective Ridha [4] developed his theory of the Caliphate. He distinguished two types of caliphate that existed in Muslim history. The first type is the caliphate under alkhulafa al-rashidun and several other caliphs after those he calls the ideal caliph. Furthermore, the second type is the actual khilafah, namely the khilafah which on the basis of its origins is divided into two parts, namely the emergency Imamat (al-Imamah al-darurah) formed because of an emergency situation because there are no candidates who really meet the requirements, and Imamat tyranny (al-taqhallub bi al-quwwah) is formed by force and coercion and is entirely dependent on its formers without having to be approved by a "defeated and bound people's assembly". Both types of Imamat, according to Ridha, demanded the obedience of the people [1].

Furthermore, according to Abu al-Hasan Ali al-Mawardi, in principle, Islamic religious government must have a strong form of political organization - in the form of leadership, both Imamate and Khilafah - that cannot be recognized by reason alone, but can be understood through the aid of revelation [8].

Regarding the constitution of the Caliphate, al-Ghazali said that the caliph should be "elected", even if only by one voter as long as he can control military power and mass obedience. The election must be continued by making loyal contracts (bai'at) of important figures, groups of people who release and bind (ahlul halli wal-'aqdi). In concrete terms, as Lambton said, this means that the caliph, whose appointment as leader was recognized by the Seljuq King, commanders, and high-ranking bureaucratic officials, must ultimately also be approved by the scholars. Thus the formal process followed the Shari'a, but the power of its constituents remained in the hands of the sultan. And then, al-Ghazali concluded that the caliph was a person who got an oath of loyalty from military leaders [8]. 
Furthermore, according to Muhammad Abduh the historical caliphate was not a theocratic political regime, in the sense that the caliph received law directly from God. The people's obedience and submission to the caliph because of their religious beliefs. Abduh stated: "The caliph was obeyed by the people not because of allegiance with justice and protection as a prerequisite, but because of religious belief, so that believers can never oppose it even if the caliph is an enemy of God's religion, because of the actions of the ruler with his religious authority, however manifestation is religion and law " [1].

After describing the nature of worldly government, Abduh went on to state that political power must be based on people's power (public will). This people's sovereignty, according to him, must be built on the basis of the principles of freedom (hurriyyah) that are integral, consultation (shura), and the constitution (qanun) which functions as the foundation of the political system [1].

Among fundamentalist thinkers, Abu Ala Maududi (1903-1979) and Sayyid Qutb (19061966) received much special attention because of their role in formulating fundamentalist ideology and also because of their strong influence over the spread of Islamic fundamentalism in many Muslim countries. Both thinkers formulated a holistic view of Islam. Maududi in his conceptualization of the Islamic state rests on its integral theology, where sharia does not recognize the separation between religion and politics or between religion and the state (Syamsuddin \& Ghazali, 2001). If so, the Islamic state conceptualized by Maududi is a Theocratic state, where the Islamic ideology formulated from a systematic elaboration of alQur'an revelation is formulated in the spirit of surrender to the unity and sovereignty of God. Maududi saw that there were four forms of ijtihad in the legislative process carried out by a consultative body (majlis-i-shura): ta'wil (interpretation), ijtihad (deducation), qiyas (analogy), and istihsan [1].

Maududi is known as the originator and thinker of the concept of the "Islamic system" (alNizham al-Islami). Maududi holds that the Shari'a is a complete scheme of life and social order that encompasses each other, and the Islamic state obtains a basic foundation on Shari'a with the principle of recognizing God's sovereignty, the authority of the Prophet, God's representative status, and using mutual consultation. Maududi can accept the concept of democracy with the term "theo-democracy", which is a religious democracy [3].

Ibn Khaldun has determined a typology of the state using benchmarks of power. Basically he described two human conditions, namely natural conditions and civilized conditions where humans are familiar with the idea of a rule of law [10]. Ibn Khaldun argues that in mulk siyasi there are two forms of rule of law, namely: 1) siyasah diniyah or Islamic nomocracy, and 2) siyasah 'aqliyah or secular nomocracy. What distinguishes the two types of nomocracy is the implementation of Islamic law in the life of the state and the law as a result of human thought [10].

The Islamic Revolution, as an embodiment of Jihad, is one of the basic views of Maududi's political theory blueprint for the rise of Islam in modern times. This stance was also adopted by Sayyid Qutb, who held that God's power affirmed a divine source from the Islamic worldview, and therefore distinguished it from all man-made ideologies, namely secularistic and materialistic ideologies [1]. In his concept of an Islamic state, Qutb stressed the importance of the socio-economic and political dimensions. He stressed that the Islamic state would guarantee equal distribution of welfare as it should be in social and political justice institutions.

Qutb places sharia in a central position in terms of state reference, where the Islamic state, laws and legislation that actually only belongs to God and consequently, sharia becomes its fundamental constitution. This belief has given rise to Qutb's theory that supreme divine 
sovereignty or hakimiyyah, as a result of textual interpretations of the verses of the Koran. In light of this theory, divine law (Islamic), is very comprehensive and avoids various human rules and authorities. Some of the non-divine majority are the taghout, which has no legitimacy, is not religious, and is a tyrant [1].

The Ottoman Caliph lost the great war, it was a national disaster, but that does not mean he never lost. Since 1699, the Ottoman Khilafah lost most of the wars they fought, but the Khilafah was still able to survive. However, the Ottoman government never faced a number of interests as they experienced when negotiating peace after the Great War. Trapped between conflicting demands between the victors and Turkish nationalists, the fall of the Ottoman Khilafah was ultimately due to the conditions of peace, not the result of the magnitude of their defeat [11].

According to Abdul Wahhab Khallaf, that power in the form of a country's security is under the control of Muslims, whereas sharia is implemented in the form of Islamic law. Abu al-Hasan al-Mawardi said in the book of al-Ahkam al-Sultaniyyah, people who become leaders are required to have seven conditions, namely: 1) must be fair, 2) knowledgeable and able to perform ijtihad both in verses and in the field of law, 3) perfect his hearing, his eyesight and his words, so that what is known can be captured, 4) physically healthy, so that they can carry out their duties properly, 5) good at arguing in fostering people's politics and regulating the benefit, 6) dare to fight against enemies, 7) the people must be from people Quraysh. Then, Shaykh Abdul Qadim Zallum, stated that the legitimate Khilafah must meet four conditions, namely: 1) Independent Power, 2) Security in the hands of Islam, 3) Implementing Islam in total, 4) Meeting the requirements of the Khalifah [7].

Abu Bakr al-Siddiq as the first caliph ever made a speech in his sermon [10], "O people really we lead you, even though we are not the best of you, if we are good, help us, if we deviate, then straighten". In the closing sermon he said, "Obey me, as long as we obey Allah Almighty and His Messenger. If we are disobedient to Allah, then there is no obedience to me for you ". Also narrated were speeches from Umar and Usman, which strengthened their faith and the people's power and accountability before him.

According to Atho Mudzhar, the Khilafah is a religious movement that is understood as a concept of state based on Islamic law and its leader is called the Caliph. The concept presupposes that the entire Islamic world is united into a single caliphate system or government. The Khilafah system claims it is not a democratic system, but rather applies the Ahlul Halli wal Aqdli system.

According to Atho, the caliphate system itself was for the first time applied to the Khulafaurrasyidin Caliphs who were explicitly the Khalifaturrasul. During the caliphate of Abu Bakr Siddiq and Umar bin Khattab, the concept of the Caliph was still pure, namely as a continuation of the Prophet. However, at the time of Uthman bin Affan, because of Uthman's nepotism, the concept of the Khilafah began to contain tribal concepts. Whereas during the time of Ali ibn Abi Talib, the content of the competition between the syam tribes within the Quraysh tribe became increasingly prominent in the Khilafah system.

Next, Atho said, during the Umayyad Daulat, the Abbasid Daulat, and the Ottoman Baniyyah, the concept of tribal content was increasingly large and rampant, even the caliphs were appointed based on heredity. Then in modern times, the concept of the Khilafah was echoed after the collapse of the Ottoman Empire (1924), and louder in the Palestinian territories and the Indian Continent. 


\section{Conclusions}

From the description above, it was found that Islam is the product of Allah's Shari'a, the Essence that first declared the existence of the foundations of freedom and human rights in theory and practice in detail protecting human dignity which would later give birth to freedom and equality. Today, Muslims are in need of the readiness of believers to fulfill God's call, to fight together with the ummah in the context of re-establishing the Islamic State. The revival of Muslims will only occur if we return to Islam, namely by believing in the Islamic creed and applying the system and its rules. If the two inseparable parts are carried out in harmony, then the Muslims will make progress.

\section{References}

[1] M. D. Syamsuddin and A. R. Ghazali, Islam dan Politik Era Orde Baru. Logos Wacana Ilmu, 2001.

[2] H. N. Umar, Deradikalisasi Pemahaman Al Quran dan Hadis. Elex Media Komputindo, 2014.

[3] H. Nashir, Islam syariat: reproduksi Salafiyah ideologis di Indonesia. Maarif Institute, 2013.

[4] M. Sjadzali, "Islam dan Tatanegara: Ajaran, Sejarah dan Pemikiran," V, UI-Press, Jakarta, 1993.

[5] M. Abdillah, "Demokrasi yang Religius: Membincang Kembali Konsep Demokrasi di Indonesia." Jakarta: UIN Syarif Hidayatullah, 2004.

[6] A. R. Z. Zainuddin and H. Sulistyo, Pemikiran politik Islam: Islam, Timur Tengah, dan benturan ideologi. Pensil-324, 2004.

[7] F. Y. Siauw, Khilafah remake. Alfatih Press, 2015.

[8] A. Black, "Pemikiran Politik Islam: Dari Masa Nabi hingga Masa Kini," Abdullah Ali. Jakarta Serambi, 2006.

[9] M. D. Rais, Teori Politik Islam. Gema Insani, 2001.

[10] T. Azhary, Negara hukum: suatu studi tentang prinsip-prinsipnya dilihat dari segi hukum Islam, implementasinya pada periode negara Madinah dan masa kini. Bulan Bintang, 1992.

[11] E. Rogan, The Fall of the Ottomans: The Great War in the Middle East. Basic Books, 2015. 